\title{
THE MECHANISM OF THE EXCRETION OF VITAMIN C BY THE HUMAN KIDNEY ${ }^{1}$
}

\author{
By ELAINE P. RALLI, GERALD J. FRIEDMAN aNd SAUL H. RUBIN \\ (From the Department of Medicine, New York University College of Medicine, and the Third \\ (New York University) Medical Division, Bellevue \\ Hospital, New York City)
}

(Received for publication July 28, 1938)

The work of numerous investigators has shown that vitamin $C$ is excreted in the urine $(1,2,3$, $4,5,6,7)$, and various suggestions have been made as to the relation between the rate of excretion and the concentration in the blood. None of the reported observations, however, are of such a quantitative nature as to afford a description of the mechanism of its excretion. The present investigation consists of a study of simultaneous inulin and vitamin $\mathrm{C}$ clearances, by means of which it is possible to determine whether the vitamin is excreted by filtration alone, by filtration with active tubular reabsorption, or by filtration with tubular excretion.

\section{PROCEDURE}

Constant intravenous infusions were used to maintain the concentrations of both inulin and vitamin $\mathrm{C}$ in the plasma at suitable levels. The concentration of vitamin $\mathrm{C}$ was varied by appropriate priming doses followed by sustaining infusions of different concentrations. Fluids were forced on the day prior to the test, and on the morning of the experiment the subject drank 2000 cc. of water. The first clearance period started 1 hour after the last dose of water. Urine was collected by catheter and the bladder was washed out with saline at the end of each collection period. Inulin was determined in plasma and urine by the method of Smith, Goldring, and Chasis (8). Vitamin $C$ was determined in plasma and urine by the 2,6-dichlorophenol indophenol titration method $(9,10)$. Some discussion has recently arisen as to the specificity of this method $(11,12)$. However, it has been shown that the effect of other reducing substances is negligible at a $\mathrm{pH}$ below 3 and if the titration

1 This investigation has been aided by a grant from the Josiah Macy, Jr., Foundation. itself is done within a period of 2 minutes (13, 14).

Heparin ( 1 per cent) was used as an anticoagulant; the blood was centrifuged immediately and $2 \mathrm{cc}$. of plasma were precipitated by adding 4 cc. of $\mathrm{H}_{2} \mathrm{O}$ redistilled in glass and $6 \mathrm{cc}$. of 10 per cent metaphosphoric acid. The mixture was centrifuged, the filtrate decanted off, and $3 \mathrm{cc}$. used for titration. All determinations were done in triplicate. The blank obtained with $3 \mathrm{cc}$. of 5 per cent metaphosphoric acid was subtracted from the average titration value of the plasma filtrates. Potassium cyanide was not added, as previous work from our own and other laboratories $(15,16)$ has shown that potassium cyanide reduces the dye and so introduces an error. The portion of urine used for vitamin $\mathrm{C}$ determination was acidified immediately with 10 per cent by volume of glacial acetic acid, stoppered and placed in the refrigerator until titrated at the end of the experiment.

It had previously been found in a series of determinations that no destruction of vitamin $\mathrm{C}$ occurred in the urine under these conditions and within this period of time (5 to 6 hours). Experiments were also done to ascertain whether inulin would reduce the dye. It was found that no reduction occurred and also that cevitamic acid did not affect the estimation of inulin in plasma or urine, owing to the fact that in the preparation of urine and plasma for the inulin determinations, vitamin $\mathrm{C}$ is completely oxidized by the addition of copper sulphate.

In all a total of 12 series of observations of three different types were done. The first type was designed to determine the vitamin $\mathrm{C}$ inulin clearance ratio at low and high plasma concentrations of the vitamin. A rapid priming infusion of $100 \mathrm{cc}$. of 12 per cent inulin was given, followed by a constant infusion of 3 per cent inulin, given at a rate of $6 \mathrm{cc}$. per minute. After a 15- 
minute interval, which was allowed for mixing time, 3 control periods of 10 minutes each were run with the plasma vitamin $C$ at its normal level. An intravenous injection containing from 1500 to $6000 \mathrm{mgm}$. of vitamin $\mathrm{C}$ was then given. Additional urine specimens were collected while the vitamin $\mathrm{C}$ concentration in the plasma was falling from this high level (Figure 1).

In this first series, the plasma concentration of the vitamin varied from 1.89 to $34.9 \mathrm{mgm}$. per cent. The vitamin $\mathrm{C}$ clearance has a low value when the plasma level is below $2 \mathrm{mgm}$. per cent, and as the plasma level is raised, the clearance rises rapidly and approaches the inulin clearance as a limiting value. This physiological relationship is illustrated in Figure 2, which shows the vitamin $\mathrm{C} /$ inulin clearance ratio in relation to the plasma level of vitamin $\mathrm{C}$ in 82 clearance periods in 4 subjects. (This figure also includes the data reported below.)

Analysis of these data suggested that the elevation of the vitamin $\mathrm{C}$ clearance at the higher plasma concentration was owing to the fact that the renal tubules reabsorb the vitamin up to some maximal limiting rate, after which any vitamin present in the glomerular filtrate is excreted in the urine. A second series of experiments, therefore, was designed to examine this point specifically. Simultaneous inulin and vitamin C clearances were determined at three steadily maintained plasma levels of vitamin $\mathrm{C}$ in the following manner. On the day prior to the observations sufficient vitamin $\mathrm{C}$ was given by mouth to raise the blood level to $2 \mathrm{mgm}$. per cent. Inulin was administered as before and three urine specimens were collected at this plasma level. Four hun-

INULIN

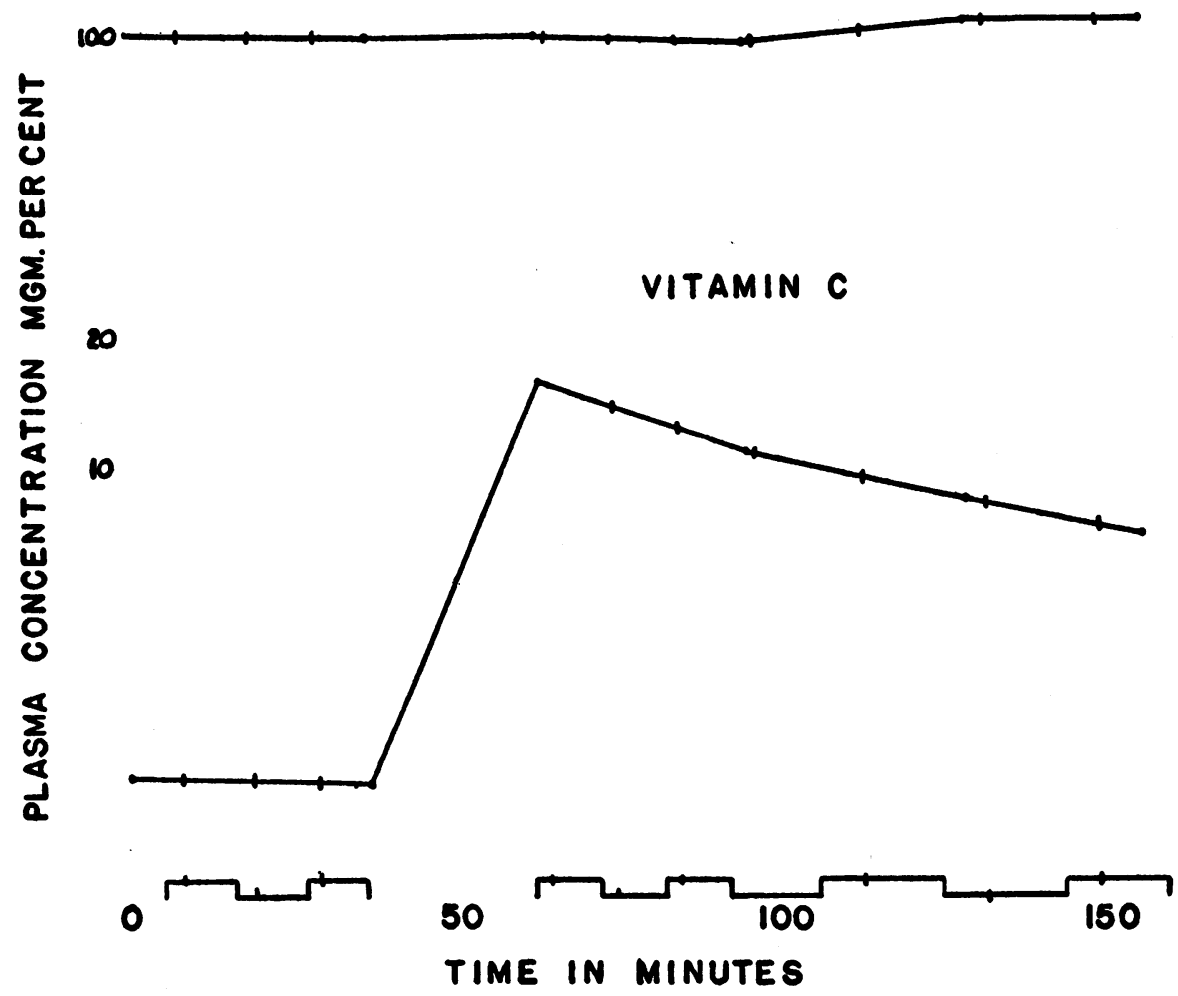

Fig. 1. Experiment Showing Vitamin C and Inulin Plasma Concentrations

The boxes at the base refer to the urine collection periods. The dots represent the plasma concentrations. The bars on the plasma curves are the values used in the calculations of the clearances. 


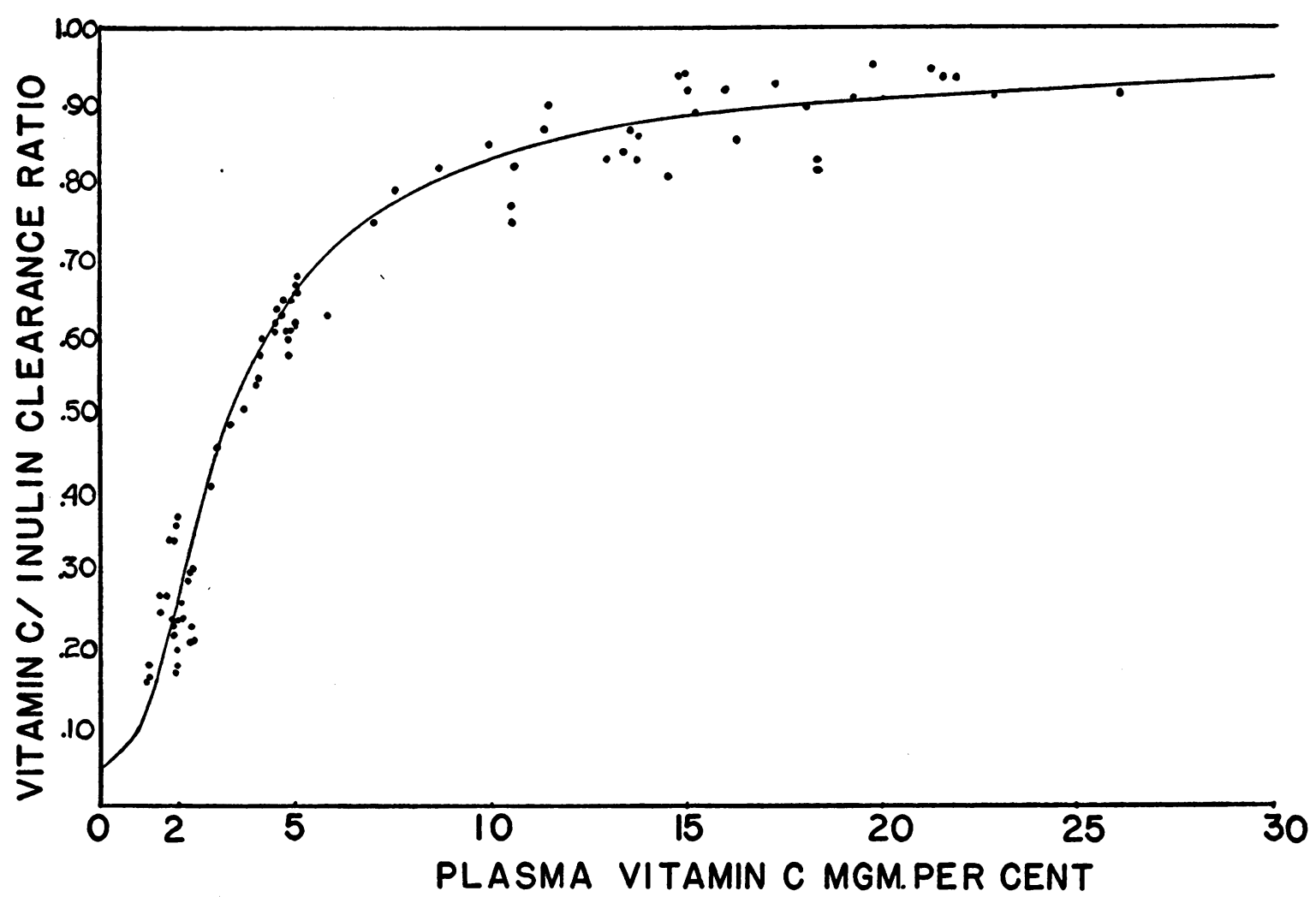

Fig. 2. Vitamin C/Inulin Clearance Ratios Plotted against Plasma Concentration of Vitamin C ratios.

The line is calculated from Equation 1 given in the text, and the dots represent the individual clearance

dred mgm. of vitamin C were injected intravenously to raise the plasma concentration to 4 $\mathrm{mgm}$. per cent. Following this, a second infusion of $450 \mathrm{cc}$. of 3 per cent inulin and an additional $400 \mathrm{mgm}$. of vitamin $\mathrm{C}$ were given to maintain the plasma concentration at this level. Three urine specimens were collected at this intermediate level. Then another priming dose of vitamin C (2000 $\mathrm{mgm}$.) was injected intravenously and the infusion changed to one containing $2000 \mathrm{mgm}$. of the vitamin in $450 \mathrm{cc}$. of 3 per cent inulin. This served to maintain the plasma level of vitamin $C$ at about $20 \mathrm{mgm}$. per cent. Three urine specimens were collected at this high plasma level. At each stage a 20-minute interval was allowed for mixing time.

The absolute amount of vitamin reabsorbed by the tubules was calculated by subtracting the amount excreted per minute from the amount filtered per minute. Assuming that the vitamin is completely filtrable from the plasma, the latter value is obtained by multiplying the inulin clearance by the plasma concentration of the vitamin. The determination of the amount reabsorbed is most accurate when the plasma level of vitamin C lies between 3 and $10 \mathrm{mgm}$. per cent, as at the higher plasma levels an error of 1 per cent in the determination of either the inulin or vitamin C clearance will introduce an error of 14 per cent in the calculation of the absolute amount of vitamin $\mathrm{C}$ reabsorbed.

Table I gives the quantity of vitamin $\mathrm{C}$ reabsorbed by the tubules in $\mathbf{5 3}$ observations in 3 subjects at 3 different plasma levels, each figure being the average of 3 observations. Expressing all functions in terms of $100 \mathrm{cc}$. of glomerular filtrate serves to eliminate in part the variations resulting from differences in the size of the kidneys in the different subjects.

These data indicate that there is in fact an absolute limitation in the capacity of the renal tubules to reabsorb the vitamin and that it is this 
TABLE I

Maximal reabsorption of vitamin $C$

\begin{tabular}{|c|c|c|c|c|c|c|c|}
\hline \multirow{2}{*}{$\begin{array}{l}\text { Sub- } \\
\text { ject }\end{array}$} & \multirow{2}{*}{$\begin{array}{l}\text { Plasma } \\
\text { con- } \\
\text { cen- } \\
\text { tration }\end{array}$} & \multicolumn{2}{|c|}{ Filtered } & \multicolumn{2}{|c|}{ Excreted } & \multicolumn{2}{|c|}{ Reabsorbed } \\
\hline & & & $\begin{array}{l}\text { Glo- } \\
\text { merular } \\
\text { filtrate }\end{array}$ & & $\begin{array}{c}\text { Glo- } \\
\text { merular } \\
\text { filtrate }\end{array}$ & & $\begin{array}{l}\text { Glo- } \\
\text { merular } \\
\text { filtrate }\end{array}$ \\
\hline P. B. & $\begin{array}{c}\text { mgm. } \\
\text { per } \\
\text { cent } \\
1.98 \\
4.94 \\
21.6\end{array}$ & $\begin{array}{c}\underset{p e r}{\operatorname{mgm} .} \\
\text { minute } \\
2.56 \\
6.17 \\
27.6\end{array}$ & $\begin{array}{c}\underset{\text { mgm. }}{\text { per }} \\
100 \mathrm{cc} . \\
1.98 \\
4.94 \\
21.6\end{array}$ & $\begin{array}{c}\underset{\text { per }}{\operatorname{mgm} .} \\
\text { minute } \\
0.47 \\
3.95 \\
26.0\end{array}$ & $\begin{array}{c}\text { mgm. } \\
\text { per } \\
100 \mathrm{cc} . \\
0.36 \\
3.16 \\
20.4\end{array}$ & $\begin{array}{c}\text { mgm. } \\
\text { per } \\
\text { minute } \\
2.09 \\
2.22 \\
1.6\end{array}$ & $\begin{array}{c}\underset{\text { per }}{\operatorname{mgm} .} \\
100 \mathrm{cc} . \\
1.62 \\
1.78 \\
1.2\end{array}$ \\
\hline P. B. & $\begin{array}{c}1.94 \\
15.1\end{array}$ & $\begin{array}{c}2.57 \\
20.3\end{array}$ & $\begin{array}{c}1.94 \\
15.1\end{array}$ & $\begin{array}{c}0.90 \\
18.7\end{array}$ & $\begin{array}{c}0.68 \\
13.9\end{array}$ & $\begin{array}{l}1.67 \\
1.6\end{array}$ & $\begin{array}{l}1.26 \\
1.2\end{array}$ \\
\hline H. M. & $\begin{array}{c}2.36 \\
5.10 \\
13.6\end{array}$ & $\begin{array}{c}2.65 \\
5.90 \\
16.3\end{array}$ & $\begin{array}{c}2.36 \\
5.10 \\
13.6\end{array}$ & $\begin{array}{r}0.58 \\
3.97 \\
14.0\end{array}$ & $\begin{array}{c}0.51 \\
3.43 \\
11.7\end{array}$ & $\begin{array}{l}2.07 \\
1.93 \\
2.3\end{array}$ & $\begin{array}{l}1.85 \\
1.67 \\
1.9\end{array}$ \\
\hline H. M. & $\begin{array}{c}2.10 \\
4.92 \\
10.6\end{array}$ & $\begin{array}{r}2.43 \\
5.58 \\
12.7\end{array}$ & $\begin{array}{c}2.10 \\
4.92 \\
10.6\end{array}$ & $\begin{array}{l}0.60 \\
3.33 \\
9.9\end{array}$ & $\begin{array}{l}0.52 \\
2.94 \\
8.2\end{array}$ & $\begin{array}{l}1.83 \\
2.25 \\
2.8\end{array}$ & $\begin{array}{l}1.58 \\
1.98 \\
2.4\end{array}$ \\
\hline L. R. & $\begin{array}{c}1.63 \\
4.14 \\
18.4\end{array}$ & $\begin{array}{c}1.99 \\
4.95 \\
24.1\end{array}$ & $\begin{array}{c}1.63 \\
4.14 \\
18.4\end{array}$ & $\begin{array}{c}0.05 \\
2.88 \\
22.4\end{array}$ & $\begin{array}{c}0.04 \\
2.40 \\
17.2\end{array}$ & $\begin{array}{l}1.94 \\
2.07 \\
1.7\end{array}$ & $\begin{array}{l}1.59 \\
1.74 \\
1.2\end{array}$ \\
\hline L. R. & $\begin{array}{r}2.30 \\
4.64 \\
18.4\end{array}$ & $\begin{array}{r}3.05 \\
6.32 \\
25.2\end{array}$ & $\begin{array}{r}2.30 \\
4.64 \\
18.4\end{array}$ & $\begin{array}{c}0.92 \\
4.00 \\
20.9\end{array}$ & $\begin{array}{c}0.69 \\
2.94 \\
15.2\end{array}$ & $\begin{array}{l}2.13 \\
2.32 \\
4.3\end{array}$ & $\begin{array}{l}1.61 \\
1.70 \\
3.2\end{array}$ \\
\hline
\end{tabular}

circumstance that leads to the increased excretion at elevated plasma levels. The agreement in the figures for the maximal rate of reabsorption is as good as may be expected in view of the possible errors in the method. Because of the nature of the calculation, the data at intermediate plasma levels are more significant than those at high plasma levels.

The third type of experiment was designed to determine whether vitamin $\mathrm{C}$ and glucose are reabsorbed by a common mechanism. This inquiry was stimulated by the fact that vitamin $C$ is closely related in chemical structure to the carbohydrates. Two series of observations were conducted on one subject in the following manner. In the first, the subject was given enough vitamin C the day before to raise the plasma level to 2 mgm. per cent. Inulin was given as before, and three 10-minute urine specimens were collected. A priming dose of $25 \mathrm{cc}$. of 50 per cent glucose was then injected, and glucose was added to the inulin infusion fluid (10 cc. per minute), in sufficient quantity to give a concentration of 10 per cent. No additional vitamin $\mathrm{C}$ was given. In a second series of observations, the plasma con- centration of glucose was maintained at 3 levels. Enough vitamin $\mathrm{C}$ was given the day before to raise the plasma level to $2 \mathrm{mgm}$. per cent, and three clearances were determined at normal plasma glucose levels. A priming dose of $50 \mathrm{cc}$. of 50 per cent glucose was then given, with a sustaining infusion of 8.3 per cent glucose (10 cc. per minute). Three urine specimens were collected at this intermediate glucose level, and then an additional $50 \mathrm{cc}$. of 50 per cent glucose was given with a sustaining infusion of 14.8 per cent glucose (10 cc. per minute). Three more urine specimens were collected at this higher plasma glucose level.

The results, given in Table II, show that when the plasma glucose is raised to levels where the glucose reabsorptive mechanism is presumably saturated, i.e. above $300 \mathrm{mgm}$. per cent (17), the reabsorption of vitamin $\mathrm{C}$ is unimpaired. From this it may be inferred that the reabsorption of vitamin $\mathrm{C}$ and of glucose do not involve a common mechanism. The data were also analyzed with a view to determining whether or not the rate of urine flow affected the excretion of vitamin C. Absolutely no relationship was found between these two when the urine flow varied from 1.5 to $15 \mathrm{cc}$. per minute.

TABLE II

Effect of hyperglycemia on the reabsorption of vitamin $C$

\begin{tabular}{c|c|c|c}
\hline $\begin{array}{c}\text { Plasma } \\
\text { vitamin C }\end{array}$ & $\begin{array}{c}\text { Plasma } \\
\text { glucose }\end{array}$ & $\begin{array}{c}\text { Vitamin C/inulin } \\
\text { clearance ratio }\end{array}$ & $\begin{array}{c}\text { Vitamin C } \\
\text { reabsorbed }\end{array}$ \\
\cline { 2 - 3 } $\begin{array}{c}\text { mgm. per cent } \\
\text { mgm. per cent } \\
2.02\end{array}$ & 88 & 0.33 & $\begin{array}{c}\text { mgm. per minute } \\
1.94\end{array}$ \\
2.00 & 88 & 0.32 & 2.17 \\
1.97 & 90 & 0.30 & 2.10 \\
\hline 1.79 & 275 & 0.60 & 1.15 \\
1.75 & 290 & 0.33 & 2.02 \\
1.70 & 310 & 0.32 & 1.68 \\
\hline 1.54 & 525 & 0.31 & 1.52 \\
1.53 & 522 & 0.27 & 1.93 \\
1.52 & 515 & 0.25 & 2.16 \\
1.52 & 510 & 0.24 & 2.15 \\
\hline
\end{tabular}

\section{DISCUSSION}

The validity of the calculation of the active tubular reabsorption depends on the assumption that the vitamin is completely filtrable at the glomeruli. This question has not been examined experimentally because of difficulties in preventing the oxidation of the vitamin, but Leblond 
(18) has reported that vitamin $\mathrm{C}$ is present in the capsular fluid of the frog in the same concentration as in the plasma. We believe that our results warrant quantitative treatment in terms of the assumption that the vitamin is also completely filtrable in man. The data indicate that vitamin $\mathrm{C}$ is excreted only by filtration, that it is actively reabsorbed by the renal tubules, and that the factor which limits this reabsorptive process is the existence of a maximal rate, such as has been demonstrated in the tubular reabsorption of glucose (17) and the tubular excretion of phenol red $(19,20,8)$, diodrast $(8)$, and a number of other substances (21). Taking only those observations in which the plasma vita$\min C$ is between 2 and $5 \mathrm{mgm}$. per cent, this maximal rate is essentially the same in each of these individuals (2.16 mgm. per minute or 1.77 mgm. per $100 \mathrm{cc}$. of glomerular filtrate).

It follows that the quantity of vitamin $\mathrm{C}$ excreted in the urine of a given individual will be determined by the plasma concentration of the vitamin, by the rate of glomerular filtration, and by the maximal rate of tubular reabsorption. Accepting this fact, we have attempted to describe the excretory process in a quantitative manner, as has been done by Shannon and Fisher (17) for glucose. To calculate the smooth curve in Figure 2 the rate of tubular reabsorption, $T_{r}$ (mgm. per minute), is calculated at various plasma concentrations of vitamin, $a$ (mgm. per cent), from Shannon and Fisher's working equation,

$$
\left(a-\frac{T_{r}}{V}\right)\left(\frac{T_{m}-T_{r}}{T_{r}}\right)=K,
$$

where $T_{m}$ is the maximal rate of tubular reabsorption, $V$ is the rate of glomerular filtration in units of $100 \mathrm{cc}$., and $K$ is a constant. In this equation, when $V$, the rate of glomerular filtration, is reduced to $100 \mathrm{cc}$. per minute, $T_{m}$ has a value of $1.77 \mathrm{mgm}$. per $100 \mathrm{cc}$. glomerular filtrate, and $K$ has a value of 0.1 . Using the values of $T_{r}$ obtained and inserting at the selected values of $a$, the vitamin $\mathrm{C} /$ inulin clearance ratio is calculated according to the equation:

Vitamin $\mathrm{C} /$ inulin clearance ratio $=1-\frac{T_{r}}{a}$.

The calculated ratio agrees satisfactorily with the observed data, and the fact of this agreement, especially at elevated plasma concentrations of vitamin $\mathrm{C}$, supports the assumption that the vitamin is completely filtrable from the plasma.

It should be noted that according to Equation 1 the vitamin $\mathrm{C}$ clearance does not become zero at very low plasma levels, but ultimately falls to a minimal value which is independent of plasma level. This minimal clearance is determined by the relative magnitudes of the constant $K$, the rate of filtration, $V$, and the capacity of the renal tubules to reabsorb the vitamin, as revealed in $T_{m}$. Probably, the theoretical minimal clearance would not be reached in any subject except in prolonged vitamin $\mathrm{C}$ deficiency. But even in view of this theoretical prediction, it is evident that the vitamin will continue to be excreted in the urine so long as it is present in the blood; i.e., the renal mechanism of reabsorption offers no safeguard against complete depletion of the vitamin in the body when the intake or synthesis is zero. Further experiments at this very low level are being done to get satisfactory data regarding this point.

Giroud and Leblond (22) studying the renal elimination of ascorbic acid by histological technique noted that when ascorbic acid was given intravenously to guinea pigs, it was found in the cells of the proximal convoluted tubules and the descending branch of Henle's loop. None was observed in the ascending branch of Henle's loop, the distal convoluted tubules, or the excretory ducts. Our observations prove that vitamin $\mathrm{C}$ is reabsorbed by the renal tubules. These observations would indicate that this process is a function of the proximal portion of the renal nephron.

\section{SUM MARY}

1. Simultaneous vitamin $C$ and inulin clearances show that vitamin $C$ is excreted by filtration and active tubular reabsorption.

2. The reabsorptive mechanism for vitamin $C$ appears to be limited by a maximal rate, so that when the vitamin is presented to the tubules by the glomerular filtrate at a rate exceeding this maximum, the excess is excreted in the urine.

3. The maximal rate of reabsorption in three individuals averages $2.16 \mathrm{mgm}$. per minute (or $1.77 \mathrm{mgm}$. per $100 \mathrm{cc}$. of glomerular filtrate).

4. The excretion of vitamin $C$ in a given individual will be determined by (1) the plasma level, (2) the rate of glomerular filtration, and (3) the 
maximal rate of tubular reabsorption. The nature of the reabsorptive process is such that at low plasma levels the vitamin $\mathrm{C}$ clearance reaches a minimal and constant value.

5. Although in chemical structure vitamin $C$ is related to the carbohydrates, it is not reabsorbed by the same mechanism as glucose.

We are indebted to Merck \& Company for the cevitamic acid used in this work.

\section{BIBLIOGRAPHY}

1. Harris, L. J., Ray, S. N., and Ward, A., The excretion of vitamin $C$ in human urine and its dependence on the dietary intake. Biochem. J., 1933, 27, 2011.

2. Youmans, J. B., Corlette, M. B., Akeroyd, J. H., and Frank, H., Studies of vitamin C excretion and saturation. Am. J. M. Sc., 1936, $191,319$.

3. Hawley, E. E., Stephens, D. J., and Anderson, G., The excretion of vitamin $C$ in normal individuals following a comparable quantitative administration in the form of orange juice, cevitamic acid by mouth and cevitamic acid intravenously. J. Nutrition, 1936, 11, 135.

4. Wright, I. S., Lilienfeld, A., and MacLenathen, E., Determination of vitamin C saturation. A 5 hour test after an intravenous test dose. Arch. Int. Med., 1937, 60, 264.

5. Wortis, H., Liebmann, J., and Wortis, E., Vitamin $\mathrm{C}$ in the blood, spinal fluid and urine. J. A. M. A., 1938, 110, 1896.

6. Faulkner, J. M., and Taylor, F. H. L., Observations on the renal threshold for ascorbic acid in man. J. Clin. Invest., 1938, 17, 69.

7. Ralli, E. P., and Friedman, G. J., The response to the feeding of cevitamic acid in normal and deficient subjects as measured by a vitamin $\mathrm{C}$ excretory test. Ann. Int. Med., 1938, 11, 1996.

8. Smith, H. W., Goldring, W., and Chasis, H., The measurement of the tubular excretory mass, effective blood flow and filtration rate in the normal human kidney. J. Clin. Invest., 1938, 17, 263.
9. Farmer, C. J., and Abt, A. F., Ascorbic acid content of blood. Proc. Soc. Exper. Biol. and Med., 1935, $32,1625$.

10. Birch, T. W., Harris, L. J., and Ray, S. N., A microchemical method for determining the hexuronic acid (vitamin C) content of foodstuffs, etc. Biochem. J., 1933, 27, 590.

11. Emmerie, A., and van Eekelen, M., The chemical determination of vitamin $\mathrm{C}$ with removal of interfering reducing and coloured substances. Biochem. J., 1934, 28, 1153.

12. van Eekelen, M., and Heinemann, M., Critical remarks on the determination of urinary excretion of ascorbic acid. J. Clin. Invest., 1938, 17, 293.

13. Harris, L. J., and Ray, S. N., Diagnosis of vitamin C subnutrition by urine analysis with a note on the antiscorbutic value of human milk. Lancet, 1935, 1, 71.

14. Harris, L. J., Chemical test for vitamin $C$ and the reducing substances present in tumor and other tissues. Nature, 1932, 132, 27.

15. Friedman, G. J., Rubin, S. H., and Kees, W., Effect of addition of $\mathrm{KCN}$ to whole blood on indophenolreducing power of plasma. Proc. Soc. Exper. Biol. and Med., 1938, 38, 358.

16. Farmer, C. J., and Abt, A. F., Invalidation of plasma ascorbic acid values by use of potassium cyanide. Proc. Soc. Exper. Biol. and Med., 1938, 38, 399.

17. Shannon, J. A., and Fisher, S., The renal tubular reabsorption of glucose in the normal dog. Am. J. Physiol., 1938, 122, 765.

18. Leblond, C. P., Méchanisme de l'élimination rénale de la vitamine C. Compt. rend. Soc. de biol., 1938, 127, 208.

19. Shannon, J. A., The excretion of phenol red by the dog. Am. J. Physiol., 1935, 113, 602.

20. Pitts, R. F., The excretion of phenol red by the chicken. J. Cell. and Comp. Physiol., 1938, 11, 99.

21. Shannon, J. A., Renal tubular excretion. Physiol. Rev. (In press.)

22. Giroud, A., and Leblond, C. P., Histological study of renal elimination of ascorbic acid. Anat. Rec., 1937, 68, 113. 